\title{
Study on Different Vegetable based Intercrops in Cabbage for Assessing Growth, Yield and Economic Viability
}

\author{
G. L. L. Mawnai*, T. B. Alloli, V. M. Ganiger, S. I. Athani, \\ P. Ajjappalavar and S. Yadachi
}

Department Vegetable Science, University of Horticultural Sciences, Bagalkot, India

*Corresponding author

\section{A B S T R A C T}

\begin{tabular}{|l|}
\hline Key w or d s \\
Intercrops in \\
Cabbage, \\
Brassica oleracea \\
\hline Article Info \\
\hline $\begin{array}{l}\text { Accepted: } \\
\text { 12 December } 2020 \\
\text { Available Online: } \\
\text { 10 January } 2021\end{array}$ \\
\hline
\end{tabular}

\section{Introduction}

Cabbage (Brassica oleracea var. capitata) commonly known as white cabbage or headed cabbage belongs to the family Brassicaceae with chromosome number $2 \mathrm{n}=2 \mathrm{x}=18$. Primarily it is regarded as one of the most economically important member of the genus Brassica. It is thought to have originated in the Mediterranean region through evolution of a wild diploid ancestor i.e Brassica oleracea var. sylvestris; a leafy kale like plant commonly known as Coleworts. It is one of the most important cole crops grown in India and throughout the world. In India it is not clearly known when it was introduced but it is accepted that it was probably introduced during the Portuguese rule and became a popular crop during the British period (Swarup, 2006). Arable lands are under pressure to produce food for human consumption, especially in developing countries in Asia and Africa where growers have own small plots of land (Awal et al., 2007). Moreover farmers are constantly looking for ways to increase their production and income through various means and practices such as the use of F1 hybrids, improved varieties, intercultural operations, plant protection and application of plant growth regulators. In this regard, Intercropping is an important agronomic 
practice that can provide farmers with an alternative means to increase production and also provide them a sustainable and steady income source.

Intercropping is the cropping system where two or more crop species are grown simultaneously in the same field area with a view to using the available interspaces for obtaining a higher productivity and maintaining better soil health. Due to the rapid increase in population and the everyday decrease in land it has become imperative to increase the productivity of our farmlands. It is known to improve soil conservation by means of increased ground cover and it also helps in utilizing different layers of the soil by way of the difference in root depths of the component crops (Zimmermann, 1996). In addition, intercropping has also proven to be a useful practice to control weeds naturally thereby reducing herbicide inputs. It offers an effective means for efficient use of resources like solar energy, water, nutrients and therefore improves crop productivity (Midmore, 1993). Fertilizers are more efficiently used in an intercropping system, due to the increased amount of humus and the different rooting systems of the crops as well as differences in the amount of nutrients taken up (Gebru, 2015). Guvenc and Yildirim (1999) opined that it is a stable system and is a safer production system especially for small farms which are devoid of capital and where labor is limited. Due to its manifold benefits it has been internationally acclaimed as the most reliable production system in maintenance of sustainable vegetable production (Coolman and Hoyt, 1993). With this in mind a study to assess the best vegetable based intercropping system on Cabbage was studied in order to find out the best combination which would produce satisfactory growth, yields and economic benefits.

\section{Materials and Methods}

The field experiment was conducted in sandy loam soil with $\mathrm{pH} 7.0$ at the Main Horticultural Research and Extension Centre (MHREC), University of Horticulture Sciences, Bagalkot (Karnataka), College of Horticulture, Bagalkot which is located in the Northern part of the state with $16.1635^{\circ} \mathrm{N}$ latitude and $75.6172^{\circ} \mathrm{E}$ longitude at an altitude of 563 meters above mean sea level.

The soil of the experimental field was red sandy loam with $65 \mathrm{Kg} \mathrm{ha}^{-1}$ nitrogen, 29.12 $\mathrm{Kg} \mathrm{ha}{ }^{-1}$ phosphorous and $168 \mathrm{Kg} \mathrm{ha}{ }^{-1}$ potassium and a $\mathrm{pH}$ of 7.43 and E.C of $0.17 \mathrm{dSm}^{-1}$. The crops methi, palak, radish, beetroot and cluster bean were used as component crops in the intercropping system. Cabbage was planted at a spacing of $45 \mathrm{~cm} \mathrm{X}$ $30 \mathrm{~cm}$ in RCBD design with four replications and the component crops of methi and palak were adjusted to be planted in two rows each in between the rows of cabbage whereas, the rest of the component intercrops were planted in single rows between cabbage rows.

Cabbage seedlings were raised and transplanted into the field followed by direct seeding of the component crops afterwards. The respective sole crops were also raised and recommended package of practices were followed for all the crops used in the study. The growth parameters of cabbage, yield parameters of cabbage as well as of intercrops and economic parameters (B:C ratio) based on prevalent market prices available to farmers were recorded for the study. The land equivalent ratio was computed to determine the efficacy of the intercrop systems as suggested by Mead and Willey, 1980. Data from the trial were subjected to analysis of variance (ANOVA) and differences between means were separated using least significant difference (LSD) at 5\% level of significance. 


\section{Results and Discussion}

\section{Growth parameters}

The observations regarding the growth parameters of cabbage viz., plant height, number of leaves, plant spread, head circumference and dry matter were recorded (Table 1) at 30 DAT and at harvest. The attributes number of leaves at harvest (15.66), plant spread at 30 DAT $\left(1875.88 \mathrm{~cm}^{2}\right)$ and head circumference $(44.66 \mathrm{~cm})$ were found significantly greater in sole cropped cabbage. The plant height of cabbage was not influenced significantly due to intercropping system which are in conformity with previous studies which indicated that the intercropping did not adversely affect the growth parameters of cabbage in comparison to mono crop (Guvenc and Yildirim, 2006). This might be due to the fact that some of intercrops used in the study have different growth patterns and maturity, as compared to cabbage.

Table.1 Effect of different intercrop treatments on cabbage growth parameters

\begin{tabular}{|c|c|c|c|c|c|c|c|}
\hline \multirow[t]{2}{*}{ SI. No } & \multirow[t]{2}{*}{ Treatment } & \multicolumn{2}{|c|}{$\begin{array}{l}\text { Plant height } \\
\text { (cm) }\end{array}$} & \multicolumn{2}{|c|}{$\begin{array}{c}\text { Number of } \\
\text { leaves }\end{array}$} & \multicolumn{2}{|c|}{ Plant spread $\left(\mathrm{cm}^{2}\right)$} \\
\hline & & $\begin{array}{c}30 \\
\text { DAT }\end{array}$ & $\begin{array}{c}\text { At } \\
\text { harvest }\end{array}$ & $\begin{array}{c}\text { 30 } \\
\text { DAT }\end{array}$ & $\begin{array}{c}\text { At } \\
\text { harvest }\end{array}$ & 30 DAT & At harvest \\
\hline 1 & Cabbage + Methi $\left(T_{1}\right)$ & 22.44 & 24.11 & 11.33 & 14.77 & 1539.21 & 1857.33 \\
\hline 2 & Cabbage + Palak $\left(\mathrm{T}_{2}\right)$ & 23.44 & 24.88 & 12.11 & 12.88 & 1479.33 & 1872.11 \\
\hline 3 & Cabbage + Radish $\left(\mathrm{T}_{3}\right)$ & 26.44 & 24.33 & 11.44 & 12.88 & 1506.55 & 2039.88 \\
\hline 4 & Cabbage + Beetroot $\left(\mathrm{T}_{4}\right)$ & 23.66 & 22.88 & 12.44 & 13.77 & 1340.10 & 1986.66 \\
\hline 5 & Cabbage+ Cluster bean $\left(\mathrm{T}_{5}\right)$ & 21.99 & 22.77 & 11.44 & 14.00 & 1530.22 & 1710.55 \\
\hline \multirow[t]{5}{*}{6} & Cabbage (Sole crop) $\left(\mathrm{T}_{6}\right)$ & 21.77 & 24.22 & 11.10 & 15.66 & 1875.88 & 2086.33 \\
\hline & Mean & 23.30 & 23.87 & 11.65 & 14.00 & 1545.22 & 1925.40 \\
\hline & SE $\mathbf{m} \pm$ & 1.38 & 0.50 & 0.36 & 0.27 & 54.69 & 90.58 \\
\hline & CV@ @\% & 11.82 & 4.20 & 6.12 & 3.81 & 7.08 & 9.41 \\
\hline & CD \% & 4.15 & 1.51 & 1.07 & 0.80 & 164.87 & 273.03 \\
\hline
\end{tabular}

Table.2 Effect of different intercrop treatments on head circumference and dry matter of cabbage

\begin{tabular}{|c|l|c|c|}
\hline $\begin{array}{c}\text { SI. } \\
\text { No }\end{array}$ & \multicolumn{1}{|c|}{ Treatment } & $\begin{array}{c}\text { Head Circumference } \\
(\mathbf{c m})\end{array}$ & Dry matter $(\mathbf{g})$ \\
\hline $\mathbf{1}$ & Cabbage + Methi $\left(\mathrm{T}_{1}\right)$ & 43.99 & 302.33 \\
\hline $\mathbf{2}$ & Cabbage + Palak $\left(\mathrm{T}_{2}\right)$ & 42.25 & 340.00 \\
\hline $\mathbf{3}$ & Cabbage + Radish $\left(\mathrm{T}_{3}\right)$ & 36.41 & 270.33 \\
\hline $\mathbf{4}$ & Cabbage + Beetroot $\left(\mathrm{T}_{4}\right)$ & 39.90 & 252.66 \\
\hline $\mathbf{5}$ & Cabbage + Cluster bean $\left(\mathrm{T}_{5}\right)$ & 41.29 & 304.66 \\
\hline $\mathbf{6}$ & Cabbage (Sole crop) $\left(\mathrm{T}_{6}\right)$ & 44.66 & 356.66 \\
\hline & Mean & 41.42 & 304.44 \\
\cline { 2 - 4 } & SE m \pm & 0.78 & 24.33 \\
\cline { 2 - 4 } & CV @ 5\% & 3.79 & 15.99 \\
\hline & CD \% & 2.36 & 73.35 \\
\hline
\end{tabular}


Table.3 Effect of intercrop treatments on cabbage yield parameters

\begin{tabular}{|c|c|c|c|c|}
\hline Sl. No & Treatment & $\begin{array}{l}\text { Weight of } \\
\text { head }(\mathrm{kg})\end{array}$ & Yield per plot (kg) & $\begin{array}{r}\text { Yield per } \\
\text { hectare }(t)\end{array}$ \\
\hline 1 & Cabbage+ Methi $\left(\mathrm{T}_{1}\right)$ & 1.19 & 30.14 & 75.34 \\
\hline 2 & Cabbage + Palak $\left(\mathrm{T}_{2}\right)$ & 1.44 & 26.25 & 63.13 \\
\hline 3 & Cabbage + Radish $\left(\mathrm{T}_{3}\right)$ & 1.11 & 16.16 & 40.41 \\
\hline 4 & Cabbage + Beetroot $\left(\mathrm{T}_{4}\right)$ & 1.25 & 32.15 & 76.26 \\
\hline 5 & Cabbage + Cluster bean $\left(\mathrm{T}_{5}\right)$ & 1.29 & 25.21 & 62.86 \\
\hline \multirow[t]{5}{*}{6} & Cabbage (Sole crop) $\left(\mathrm{T}_{6}\right)$ & 1.56 & 33.27 & 83.19 \\
\hline & Mean & 1.31 & 27.20 & 66.87 \\
\hline & SE $\mathbf{m} \pm$ & 0.07 & 1.73 & 4.15 \\
\hline & CV@ 5\% & 10.37 & 12.69 & 12.40 \\
\hline & CD \% & 0.20 & 5.20 & 12.50 \\
\hline
\end{tabular}

Table.4 Effect of intercropping system on economics of production of cabbage and component crops

\begin{tabular}{|c|c|c|c|c|c|c|c|}
\hline Sl. No & Treatments & $\begin{array}{l}\text { Total yield } \\
\text { (t/ha) }\end{array}$ & $\begin{array}{c}\text { Intercrop } \\
\text { yield } \\
\text { (t/ha) }\end{array}$ & $\begin{array}{c}\text { Cost of } \\
\text { Cultivati } \\
\text { on } \\
\text { (Rs./ha) }\end{array}$ & $\begin{array}{c}\text { Gross } \\
\text { return } \\
\text { (Rs./ha) }\end{array}$ & $\begin{array}{c}\text { Net } \\
\text { return } \\
\text { (Rs./ha) }\end{array}$ & $\begin{array}{l}B: C \\
\text { ratio }\end{array}$ \\
\hline 1 & Cabbage + Methi $\left(\mathrm{T}_{1}\right)$ & 75.34 & 4.04 & 62000 & $4,02,940$ & $3,40,940$ & 5.49 \\
\hline 2 & Cabbage + Palak $\left(\mathrm{T}_{2}\right)$ & 63.13 & 10.95 & 61500 & $3,59,450$ & $2,97,450$ & 4.84 \\
\hline 3 & Cabbage + Radish $\left(\mathrm{T}_{3}\right)$ & 40.41 & 24.00 & 61500 & $2,98,050$ & $2.36,550$ & 3.84 \\
\hline 4 & Cabbage + Beetroot $\left(\mathrm{T}_{4}\right)$ & 76.26 & 4.70 & 62500 & $4,00,100$ & $3,37,600$ & 5.40 \\
\hline 5 & Cabbage + Cluster bean $\left(\mathrm{T}_{5}\right)$ & 62.86 & 0.90 & 63000 & $3,21,500$ & $2,58,500$ & 4.10 \\
\hline 6 & Cabbage (Sole crop) $\left(\mathrm{T}_{6}\right)$ & 83.19 & - & 60000 & $3,32,760$ & $2,72,760$ & 4.55 \\
\hline 7 & $\operatorname{Methi}\left(\mathrm{T}_{7}\right)$ & 12.94 & - & 10000 & 38,820 & 23,820 & 1.58 \\
\hline 8 & Palak $\left(\mathrm{T}_{8}\right)$ & 23.38 & - & 12000 & 69,900 & 49,900 & 2.49 \\
\hline 9 & Radish $\left(\mathrm{T}_{9}\right)$ & 38.00 & - & 20000 & $1,14,000$ & 89,000 & 3.56 \\
\hline 10 & Beetroot $\left(\mathrm{T}_{10}\right)$ & 17.53 & - & 20000 & 52,590 & 27,590 & 1.01 \\
\hline 11 & Cluster bean $\left(\mathrm{T}_{11}\right)$ & 2.27 & - & 10000 & 18,160 & 8,160 & 0.82 \\
\hline
\end{tabular}

(Cabbage price/kg; Rs.5, Palak price/kg: Rs. 4, Methi price/kg: Rs.6, Beetroot Price/kg: Rs.4, Cluster Bean/kg: Rs. 8, Radish price/kg: Rs.4)

Table.5 Land equivalent ratio of various cabbage based intercropping treatments

\begin{tabular}{|c|l|r|}
\hline SI no. & \multicolumn{1}{|c|}{ Treatment } & LER \\
\hline $\mathbf{1}$ & Cabbage + Methi $\left(\mathrm{T}_{1}\right)$ & 1.24 \\
\hline $\mathbf{2}$ & Cabbage + Palak $\left(\mathrm{T}_{2}\right)$ & 1.23 \\
\hline $\mathbf{3}$ & Cabbage + Radish $\left(\mathrm{T}_{3}\right)$ & 1.12 \\
\hline $\mathbf{4}$ & Cabbage + Beetroot $\left(\mathrm{T}_{4}\right)$ & 1.18 \\
\hline $\mathbf{5}$ & Cabbage + Cluster bean $\left(\mathrm{T}_{5}\right)$ & 1.15 \\
\hline
\end{tabular}


Intercropping has been reported to be more productive when their component crops differ greatly in growth duration so that their maximum requirement for growth resources occur at different times (Fukai and Trenbath, 1993). The significant differences were noticed with respect to number of leaves at harvest, plant spread (at 30 DAT) and head circumference which were in accordance with earlier studies wherein some growth parameters of cabbage were affected particularly when it was intercropped with beetroot and radish (Choudhuri, 2016; Guvenc and Yildirim, 2006).

These findings may be attributed to increased competition for light, space and nutrients among the intercrops. Moreover, beetroot being a crop of similar growth duration as that of cabbage might have competed with cabbage for resources sharing particularly at the initial stages of growth of the crops thereby reducing the plant spread of cabbage. Intercropping did not produce a pronounced effect on the total dry matter of cabbage head (Table 2) which are in confrontation with the studies by Ananda et al., (2018) who reported that the dry matter was maximum in cabbage grown as sole crop.

\section{Yield parameters}

The effect of intercropping on the yield parameters of cabbage viz., weight of head, yield per plot and yield per hectare is presented in table 3 . The analyzed data on the points to the notion that sole cropped cabbage recorded maximum values in yield attributes. Cabbage as sole crop recorded the maximum weight of head $(1.56 \mathrm{~kg})$, yield per plot $(33.27$ $\mathrm{kg}$ ) and yield per hectare (83.19 tonnes). Weight of cabbage head was significantly influenced by intercropping which was in accordance with previous studies by Ananda et al., (2018). The treatment of cabbage intercropped with palak showed good head weight which might be a result of improved resource sharing, as the long duration crop had an opportunity to utilize nutrients and space thereby increasing their yield (Guvenc and Yildirim, 2006). The yield per plot was least in cabbage intercropped with radish which are again in line with studies by Guvenc and Yildirim, 2006 who reported that radish seem to have negative impact on yield and growth characteristics of cabbage. The data on yield per hectare points out that sole crop of cabbage provided higher yields as compared to intercrop treatments. Qasim et al., 2013 and Yildirim and Guvenc et al., 2005 reported higher yields in sole cropped vegetables as compared to intercropped counterparts. It is widely reported that in most cases the main crop in an intercropping system does not perform as well as it should as in monoculture and does not reach as high a yield level due to an increased competition among intercropped plants for light, soil nutrients and water (Willey, 1979). Similar reports by Ananda et al., (2018) reported reduced performance of cabbage as intercrop which might be owned to the fact that sole cropped cabbage showed better performance in terms harvest index, net assimilation rate, plant growth efficiency, crop growth rate and relative growth rate. Poor performance of intercropped cabbage for these attributes may have caused negative impact on the yield parameters of cabbage as an intercrop. The yield per hectare among the intercrop treatments showed that cabbage + beetroot at $76.26 \mathrm{t} / \mathrm{ha}$ and cabbage + methi at $75.34 \mathrm{t} / \mathrm{ha}$ performed well as compared to the other treatments. The treatment of cabbage with methi was however more desirable as methi showed better performance as an intercrop with higher LER (Table 5). This is in confirmation with studies conducted by Gawade et al., (2002) highlighting the finding that cabbage with methi gave higher LER, indicating higher efficiency of the combination in resource utilization. 


\section{Economic parameters}

After perusal of data (Table 4) the total cost cultivation for cabbage ranged from Rs. 60,000 per hectare in cabbage as a sole crop to Rs. 63,000 per hectare in cabbage grown with cluster bean. Among the sole crop treatments, the least cost incurred was found in cluster bean at ₹ 10000 and the highest cost incurred in cabbage at Rs. 60,000. The gross return ranged from Rs. 4, 02,940 per hectare in cabbage intercropped with methi to Rs. 18,160 per hectare in cluster bean sole crop and the Net returns data revealed that the maximum net return was obtained in cabbage intercropped with methi at Rs. 3, 40,940 per hectare and the least net return in cluster bean sole crop at Rs. 8,160 per hectare. The data obtained from the economics of production revealed that all the treatments had a benefit cost ratio greater than 1 which shows that the cropping enterprise studied were beneficial from the economics point of view (Table 4). Economic feasibility data showed that except for the intercropping combinations viz., cabbage with radish (3.84) and cabbage with cluster bean (4.10) the observed B:C ratio was higher than that of sole crop of cabbage (4.55). The findings of this study are contrary to reports by Chavan et al., (2010) who reported that intercropping gave higher returns than sole cropping of cabbage. The lower B:C ratio obtained in these two treatments could be attributed to the significantly lower cabbage yield that these two combinations produced. This might be due to increased competition of cabbage and incompatible relationships with these intercrop components. Guvenc and Yildirim (2006) opined that radish reduced the yield of cabbage due to the release of cyanides and chemical compounds such as glucosinolates which affected the surrounding plants. The highest $\mathrm{B}: \mathrm{C}$ ratio was recorded when cabbage was intercropped with methi. The second highest $\mathrm{B}: \mathrm{C}$ ratio was noticed in cabbage intercropped with beetroot which could be attributed to the high yield due to over dominance of cabbage over beetroot. Cabbage intercropped with methi seems to have the most balanced overall performance as evident to this combination recording the highest $\mathrm{B}: \mathrm{C}$ ratio, with relatively good quality cabbage heads, yields, the highest weed smothering efficiency and the highest LER (1.24) indicating this combination efficiency in resource utilization.

\section{Land equivalent ratio}

Data on land equivalent ratio showed values higher than 1 which signifies the efficiency of intercrops in using the environmental resources over mono cropping. Highest LER values of 1.24 were obtained in cabbage intercropped with methi which are in conjuncture with Gawade et al., (2002) and Singh (1997) who reported the LER to be highest in cabbage with methi intercropping combination.

In conclusion with the ever increasing population and decrease in the land available for cultivation coupled by the growing demand for environmentally safe and sustainable ways to produce crops, intercropping can act as a reliable tool in answering these questions due to its array of benefits. The results of the present study revealed that the growth and yield characteristics of cabbage were affected by intercropping especially producing negative impacts when grown with radish. However, intercropping with methi had produced several desired effects both in terms of yield, economics and productivity as evident from the increased LER.

\section{References}

Awal, M.A., Pramanik, M.H.R. and Hossen M.A., 2007, Interspecies competition, 
growth and yield in barley-peanut intercropping. Asian J. Plant Sci., 6: 577-584.

Ananda, A., Devi, A. B., Barik, S. P., Konthoujam, J. and Bairwa, M. K., 2018, Effect of Growth, Physiological Aspects and Yield of Cabbage (Brassica oleracea L. cv Rareball) in Knol khol and Broad Bean Intercropping System under Imphal West Condition. Int. J. Curr. Microbiol. App. Sci., 7(10): 11111117.

Chavan, N. H., Naik, D. M., Borade, R. S., Shinde, S. J. and Jature, S. D., 2010, Effect of intercrops on yield of cabbage at different levels of fertilizers. Int. J. Agric. Sci., 6(1): 291-294.

Choudhuri, P., 2016, Intercropping in cabbage (Brassica oleracea L. var. capitata f.) for growth, yield, quality and sustainable soil health under foothills of Eastern himalayan region. J. Appl. Nat. Sci., 8: 1740-1747.

Coolman, R.M. and Hoyt, G.D., 1993, Increasing sustainability by intercropping. Hort Technology., 3: 309311.

Fukai, S and B.R. Trenbath, 1993. Processes determining intercrop productivity and yields of component crops. Field Crops Res., 34: 247-271.

Gawade, M.H., Patil, J.D. and Kakade., 2002, Studies on effect of intercrops on yield and monetary returns of cabbage. Agric. Sci. Digest., 22 (1): 63 - 64.
Guvenc, I. and Yildirim, E., 2006, Increasing Productivity with Intercropping Systems in Cabbage Production. J. Sustain. Agric., 28(4): 29-44.

Yildirim, E. and Guvenc, I., 2005, Intercropping based on cauliflower: more productive, profitable and highly sustainable. Eur. J. Agron., 22(1):11-18.

Gebru, H., 2015, A review on the comparative advantages of intercropping to monocropping system. Journal of Biology, Agriculture and Healthcare., 5(9): 1-13.

Swarup V. 2006. Vegetable science and technology in India, Kalyani, India, 350351.

Mead, R. and Willey, R. W., 1980, The concept of a 'land equivalent ratio' and advantages in yields from intercropping. Exp. Agric., 16(3), 217228.

Zimmermann, M.J.O., 1996, Breeding for yield, in mixtures of common beans (Phaseolus vulgaris L.) and maize (Zea mays L.). Euphytica., 92: 129-134.

Singh, R. V., 1997, Production potential and economics of vegetables intercropped with cabbage. Indian J. Hortic., 54(3): 247-250.

Willey, R. (1979). Intercropping-its importance and research needs: Part 1. Competition and yield advantages. In Field crop abstracts (Vol. 32, pp. 110.

\section{How to cite this article:}

Mawnai, G. L. L., T. B. Alloli, V. M. Ganiger, S. I. Athani, P. Ajjappalavar and Yadachi, S. 2021. Study on Different Vegetable based Intercrops in Cabbage for Assessing Growth, Yield and Economic Viability. Int.J.Curr.Microbiol.App.Sci. 10(01): 1662-1668. doi: https://doi.org/10.20546/ijcmas.2021.1001.194 